Valerie Knight $^{1}$

\title{
Simon and the Tradition of the Latin Alexander of Tralles
}

Certainly from the late eighth/early ninth century, the Greek Therapeutica of the sixth-century Byzantine physician Alexander of Tralles was transmitted in a Latin translation, but with significant additions to, and omissions from, the Greek text. This paper will present evidence from the Clavis sanationis that confirms Simon's use of the Latin version and will examine the Latin manuscript tradition of specific entries. It will also briefly consider the glosses attributed to Simon in the 1504 (Lyons) printing, Practica Alexandri yatros greci cum expositione glose interlinearis lacobi de Partibus et lanuensis in margine posite, edited by Fr. Fradin.

In the preface (Section 4) of the Clavis sanationis, Simon tells us that 'after Dioscorides' (post Diascoridem) he 'carefully examined' (diligenter inspexi) the work of one 'Alexander' (Alexandri).

Simon's 'Alexander' is the sixth-century Byzantine physician Alexander of Tralles who, having settled at an unknown date in Rome and following a long

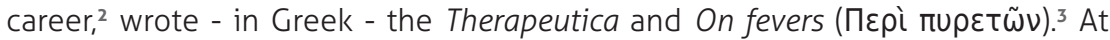
some stage, both these works were translated into Latin - certainly by the late eighth/early ninth century, the date of the oldest extant manuscript. David Langslow has called the combination of these two translations the 'Latin Alexander'.4

$\mathbf{1}$ The author is a (part-time) PhD student at the University of Manchester, funded by the Arts and Humanities Research Council (AHRC).

2 For Alexander's dates and life, see David Langslow, The Latin Alexander Trallianus: The text and transmission of a Late Latin medical book. (London: Society for the Promotion of Roman Studies, 2006), 1-4 and notes. I would like to thank David Langslow for allowing me to quote extensively from his book, The Latin Alexander Trallianus (2006), and for kindly giving me free access to his electronic transcript of Angers, Bibl.mun. 457, as well as for his helpful observations on reading the first draft of this paper. My thanks also to the anonymous reviewers for their invaluable comments. Last, but certainly not least, I thank Barbara Zipser for all her help and encouragement. All errors, oversights and misunderstandings are entirely mine.

3 Alexander also wrote a third work, in the form of a letter, On intestinal worms (Пદ $\dot{\varepsilon} \lambda \mu(v \theta \omega \nu)$. For a discussion of Alexander's writings, including details of two works ascribed to Alexander that are regarded as spurious (On eyes - Пعрі ò $\varphi \theta \alpha \lambda \mu \tilde{\omega} \nu$ - and On the pulse and urine), see Langslow The Latin Alexander Trallianus..., 4-6 and references therein.

4 Ibidem, 5 and n. 33. 
Alexander's Therapeutica therefore exists in two distinct traditions, one Greek and one Latin.

There are eighteen known manuscripts containing all or part of the Greek Therapeutica, ranging in date from the tenth to the seventeenth century, ${ }^{5}$ with the first edition printed in 1548 . The most recent edition is that of Theodor Puschmann, a doctor himself, published in two volumes in 1878-1879. ${ }^{6}$

There are twenty-one known complete manuscript copies of the Latin Alexander, nineteen of which are extant, ranging in date from the late eighth/ early ninth to the sixteenth century. ${ }^{7}$ (See Appendix 1 for a full list of these manuscripts, including the sigla used by Langslow in his 2006 book The Latin Alexander Trallianus). ${ }^{8}$ The Latin Alexander was first printed in 1504 at Lyons as the Practica Alexandri yatros greci. ${ }^{9}$ It is divided into three books: Book 1 contains chapters dealing with hair-loss to pleuritis; Book 2, chapters dealing with coughing to gout; and Book 3, chapters dealing with fevers. (See Appendix 2 for Langslow's stemma, showing the relationship between the manuscripts containing the Latin Alexander and the 1504 Lyons edition. $)^{10}$

Given that Alexander's Therapeutica exists in both Greek and Latin, the question arises as to which version did Simon use - or, indeed, did he utilise both? Two statements made by Simon are certainly evidence that he has used the Latin Alexander. The first of these is found in Section 4 of Simon's preface: ${ }^{11}$

5 Ibidem, 13 and nn. 1-4. For details of these manuscripts and a stemma showing the relationship between them, see Barbara Zipser, "Die Therapeutica des Alexander Trallianus: Ein medizinisches Handbuch und seine Überlieferung," in Rosa Maria Piccione and Matthias Perkams (Eds.), Selecta Colligere, II. Beiträge zur Methodik des Sammelns von Texten in der Spätantike und in Byzanz (Collana Hellenika). (Alessandria: Edizioni dell'Orso, 2005), 211-234.

6 All references to the Greek Therapeutica in this paper are to Theodor Puschmann, Alexander von Tralles. Original-Text und Übersetzung nebst einer einleitenden Abhandlung. Ein Beitrag zur Geschichte der Medicin, 2 vols (repr. 1963, Amsterdam: A. M. Hakkert), (Vienna: W. Braumüller, 1878-1879), giving volume (I or II), page and (where appropriate) line number.

7 Langslow, The Latin Alexander Trallianus..., 37, notes that '... the manuscript tradition of the Latin Alexander... is one of the richest, if not the richest, known for such an early medieval Latin medical text as the Latin Alexander must be, in particular for such a long text'.

8 Ibidem, 37-8; for full details of the individual manuscripts, see also: 40-53.

9 Practica Alexandri yatros greci cum expositione glose interlinearis lacobi de partibus et lanuensis in margine posite, edited by Fr. Fradin.

10 Reproduced from Langslow, The Latin Alexander Trallianus..., Plate XII, with the kind permission of David Langslow.

11 Generally, throughout this paper, where no apparatus existed (at the time of writing) on the Simon Online website, I present both the transcription of A (the 1510 printing) taken from the website, alongside my transcription of B (the 1473 printing). Here, I have underlined differences between the two versions. 
Preface, § 4 (Transcript A, 1510, last accessed 12.03.12)

Post Dyascoridem Alexandri librum de pratica [sic] dilligenter inspexi qui qui quamvis tribus distinguitur libellis: tertius qui de febribus est: nec veritatem in nominibus neque tanti philosophi seriem videtur plenius continere.

Preface, § 4 (Print B, 1473)

post Diascoridem Alexandri librum de pratica [sic] diligenter inspexi qui quamvis tribus distinguatur libellis tertius tamen qui de febribus est nec ueritatem in omnibus nec tanti philosophi seriem uidetur plenarie continere.

After Dioscorides I carefully examined the book of Alexander on pra[c]tica which although it is divided up in three books, nevertheless the third [book] which is on fevers seems to fully contain neither accuracy in everything nor the context of such a great philosophus.

Simon's description of the work being divided into three books, with the third book being on fevers, is a description of the Latin Alexander. As well as the Lyons 1504 edition, all the extant Latin manuscripts, except one, transmit the Latin Alexander in three books, the exception being P3: Paris, BNF lat. 6882. ${ }^{12}$ This is in stark contrast to the Greek tradition, where the division is either into eleven or twelve books. ${ }^{13}$

In the second, found in the latter part of his moderately lengthy entry for sauich, Simon explicitly refers to the use of an Alexander 'translated from the Greek':

Sauich (Print B, 1473)14

... notandum tamen quod ubicumque habetur in liberis [sic] de arabico translatis sauich apud Dia. et Alex. et Paul(_) et alios de greco translatos habetur polenta quare secudum [sic] idem uidetur apud grecos nero uocatur alfita ut patet per Gal(_).

12 Langslow, The Latin Alexander Trallianus..., 18-19.

13 See Zipser, "Die Therapeutica des Alexander Trallianus...", especially p.222. It is worth noting that there is an early thirteenth-century, Spanish or Catalonian, manuscript that transmits the Latin On fevers (De febribus) independently, a transmission that has no parallel in the Greek tradition (Langslow, The Latin Alexander Trallianus..., 5 n. 33, referring to the manuscript Barcelona, Archivo de la Corona de Aragón, Ripoll 181; see ibid. 90 and 92 for further details and bibliography for this manuscript).

14 Cf. Print A (last accessed 26.10.12): notandum tamen quod ubicumque habetur in libris de greco [with apparatus: 'de greco ACDOR | de arabico B efgz'] translatis sauich apud Dya. et Alexan. Paulum et alios de greco translatos habetur polenta quare secundum hoc idem videtur apud grecos vero vocatur alfitis in li. de alimentis. Item Ste. in synonimis dicit quod alfiton est sauich. 
ca. de alfitis in libro de alimentis item Ste. in sinonimis dicit quod alfiton est sauich. ... Note, however, that everywhere it is written in books translated from Arabic [it is] sauich; in the writings of Dioscorides and Alexander and Paul and others translated from the Greek, it is written polenta, for which reason we may assume they are synonyms. Among the Greeks, indeed, it is called alphita, as is revealed through Galen in the chapter on alphita in his book On foods. Likewise Stephanus in his Synonyms says that alphita is sauich.

On Dioscorides, see Marie Cronier in this volume. With regard to Paul, Peter Pormann notes that Paul's 'Book III on diseases from tip to toe was translated into Latin in 11th c. south Italy.'15

What further evidence is to be found that Simon used the Latin Alexander and is there any evidence at all to suggest that Simon may have used the Greek Therapeutica? To explore this question, it is first necessary to consider the differences between the Greek Therapeutica and the Latin Alexander. ${ }^{16}$ These differences range from what might be thought of as relatively minor discrepancies - from a single word to several sentences ${ }^{17}$ - to what can only be considered as major variations in content.

The Latin Alexander contains a considerable number of glosses, ${ }^{18}$ which are described by Langslow as:

... [the] more elaborate explication, of technical terms and concepts which are employed, usually without explanation, ${ }^{19}$ in the Greek original ... Usually, these involve either simply highlighting that the word is Greek ... or providing a Latin gloss or terminological equivalent ... [28] ... usually with an explicit reference to Greek terminology ...20

Significant sections found in the Greek Therapeutica are missing from the Latin Alexander. In Book 1 of the Latin Alexander some remedies for epilepsy present in the Greek text are missing. In Book 2, a larger number of remedies

15 Peter Porman, "Paulos of Aigina (ca 630 - 670 CE?)," in Paul T. Keyser and Georgia L. Irby-Massie (Eds.), The encyclopedia of ancient natural scientists. (London and New York, NY: Routledge, 2008), 625.

16 For a comparison of the Greek Therapeutica and the Latin version, see Langslow, The Latin Alexander Trallianus..., 17-35.

17 Langslow, The Latin Alexander Trallianus..., 20-4.

18 See ibidem $27-8$ and notes.

19 'Note, however, e.g. 2.258: "ad eos (scil. neruos) quos Graeci ankilas uocant" (beside II,

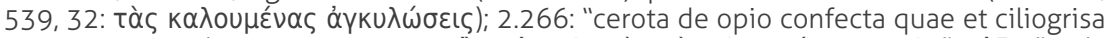

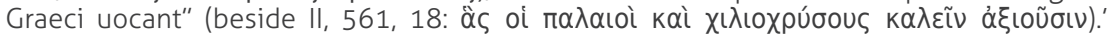
Ibidem, 27 n. 29.

20 Ibidem, 27-8. 
on coughing, as well as the chapters on hiccoughing, suppurations in the lung, dysentery and paralysis are missing. Also missing from Book 2 is a considerable amount of material from the end of the section on gout. Book 3 has nothing on tertian, quotidian or quartan fevers, stopping abruptly at the end of the chapters on hectic fevers. ${ }^{21}$

\section{The Latin Alexander: significant omissions from the content of the Greek} Therapeutica $^{22}$

Book 1: I.567-73, 'further remedies' (for epilepsy)

Book 2: II.169-83, 'further remedies for coughing'

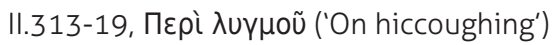

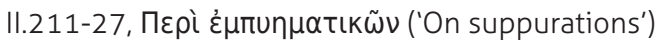

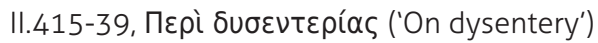

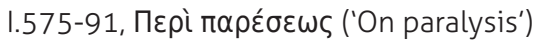
II.577.1-85.24, 'additional material on gout'

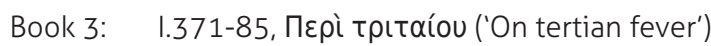

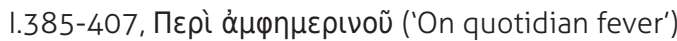

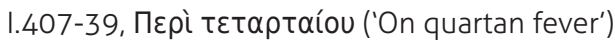

The Latin Alexander contains significant sections of text that are not found in the Greek Therapeutica. In Book 1 of the Latin Alexander, five chapters on diseases of the nose, face, and teeth have been added. In Book 2, extensive extracts of two lost Greek works, translated into Latin, have been added. The first of these is from what was originally a work of Philumenus, a second-century physician and contemporary of Galen, ${ }^{23}$ on dysentery and diseases of the intestine. The second is from what was originally a work of the fourth-century Greek physician Philagrius, ${ }^{24}$ on diseases of the spleen.

\section{See ibidem, 17.}

22 Adapted from Langslow, The Latin Alexander Trallianus..., 15-16, Table 2.1 (ed., P1, A and $\mathbf{M})$, where the references in the right-hand column are to volume (I or II) and page number in Puschmann, Alexander von Tralles...

23 David Langslow, Medical Latin in the Roman Empire. (Oxford and New York, NY: Oxford University Press, 2000), 72. For Philumenus, see Jean-Marie Jacques, "Philoumenos of Alexandria (150 - 190 CE)," in Paul T. Keyser and Georgia L. Irby-Massie (Eds.), The encyclopedia of ancient natural scientists. (London and New York, NY: Routledge, 2008), 661-662.

24 '[A] much-cited fourth-century Greek doctor from Epirus' (Langslow, Medical Latin..., 72). For Philagrius, see also John Scarborough, "Philagrios of Ëpeiros (300 - 340 CE)," in Paul T. Keyser and Georgia L. Irby-Massie (Eds.), The encyclopedia of ancient natural scientists. (London and New York, NY: Routledge, 2008), 643-644. 
The Latin Alexander: significant additions to the content of the Greek Therapeutica

Book 1: 1.131-5, 'Nose, face and teeth' (Lyons 1504, 26r-28r)

Book 2: $\quad$ 2.79-103, 'Philumenus, on the stomach and intestines'

2.79: De reumate ventris Filominis ${ }^{25}$ [sic] (Lyons 1504, 47r)

2.104-50, 'Philagrius, on the spleen'

2.104: Ad splenem Philagrius (Lyons 1504, 53r)

One good indicator that Simon was utilising the Greek Therapeutica would be if there were any entries in the Clavis sanationis that could be identified as being taken only from those sections in the Greek text that are completely absent from the Latin Alexander. Evidence that Simon has used only the Latin Alexander would be if entries in the Clavis sanationis were to be found exclusively in those sections of the Latin Alexander that are not present in the Greek Therapeutica: for example in the Philumenus and Philagrius sections, and the glosses. A third possibility is that Simon has primarily used the Latin Alexander and then supplemented an entry with additional information acquired from the Greek Therapeutica.

I have identified many entries in the Clavis sanationis that are taken from the extensive extracts from Philumenus and Philagrius which have been incorporated into Book 2 of the Latin Alexander (please see Appendices 3 and 4 for details of these). One of these entries, acantis egyptia (where akanthos (äk $\alpha \nu \theta 0 \varsigma$ ) is 'Bear's-foot'), ${ }^{26}$ contains another explicit reference to the 'Practica of Alexander' (i.e., the Latin Alexander):

Acantis egyptia (Transcript A, 1510, last accessed 12.03.12)

Acantis egyptia invenitur in practica Alexandri in confectione collirii ad tingenda leucemata puto quod sit idem quod achantis arabica.

Acantis egyptia (Print B, 1473)

Achantis egiptiaca [sic] inuenitur in pratica [sic] Ale. in confectione colirii [sic] ad tingenda leucomata puto quod sit idem quod achantis ara.

Egyptian acantis is found in the Practica of Alexander in a preparation of an eye salve for bathing white spots [white corneal opacities]. I think that it is the same as Arabic acantis.

25 In my transcriptions, where the witnesses print ' $u$ ' or ' $v$ ', I have printed ' $u$ ' or ' $v$ ' respectively throughout.

26 See Lily Y. Beck, Pedanius Dioscorides of Anazarbus: De materia medica (2nd edn). (Hildesheim, Zürich and New York, NY: Olms-Weidmann, 2011), 186 (Dioscorides III.17). 
Furthermore, this particular entry represents an example of Simon's use of only the Latin Alexander. I would like to detail the method used to verify this, partly in order to illustrate the complexity in locating the exact source of Simon's information, but mainly to serve as an example of an investigation which did briefly raise the prospect that Simon had used the Greek Therapeutica.

To identify where in the Latin Alexander 'Egyptian acantis' is to be found, I used Opsomer's invaluable Index de la pharmacopée du ler au Xe siècle ${ }^{27}$, which lists three entries for 'Acanthus Aegyptia' in the Lyons 1504 edition - in Book 2, Chapters 79, 80 and 98 - all of which are in the Philumenus section of the Latin Alexander; and one entry for 'Acanthi Aegyptiae Semen', in Book 2, Chapter 123 - the Philagrius section:

Latin Alexander [Philumenus] 2.79: De reumate ventris Filominis [sic] (Lyons 1504, 47r-48v)

48r: acantis ${ }^{28}$ egiptiace $[\text { sic }]^{29}$

Latin Alexander [Philumenus] 2.80: De dissinteria reumatica (Lyons 1504, 48v-49r) 48v: achantem ${ }^{30}$ egyptiam ${ }^{31}$

Latin Alexander [Philumenus] 2.98: Enema ad dissintericos et dolores nimios vel inflammationes (Lyons 1504, 51v-52r)

52r: achanthos ${ }^{32}$ egyptie $^{33}$

Latin Alexander [Philagrius] 2.123: De fomentationibus (Lyons 1504, 55r-55v)

55v: egyptie ${ }^{34}$ acautis $[\text { sic }]^{35}$ semen

27 Carmelia Opsomer, Index de la pharmacopée du ler au Ke siècle, 2 vols. (Hildesheim, Zürich and New York, NY: Olms-Weidmann, 1989).

28 + gloss 'l': 'id est spine albe.' (48r).

29 Cf. Peter Mihăileanu, Fragmentele latine ale lui Philumenus şi Philagrius. (Bucharest: Institutul de Arte Grafice 'Carol Göbl', 1910), 110.7: acantis aegyptias [+ variants]; cf. Theodor Puschmann, Nachträge zu Alexander Trallianus: Fragmente aus Philumenus und Philagrius (repr. 1963, Amsterdam: A. M. Hakkert), (Berlin: S. Calvary and Co., 1886), 24 : acanthi Aegyptiacae [no variants].

30 + gloss 'c': 'id est spinam al(_)s.' (48v).

31 Cf. Mihăileanu, Fragmentele latine..., 116.10: acantem egyptiam [+ variants]; cf. Puschmann, Nachträge zu Alexander Trallianus..., 32: acanthum Aegyptiacam [no variants].

32 + gloss ' $z$ ': 'id est spine albe.' (52r).

33 Cf. Mihăileanu, Fragmentele latine..., 139.11: acantis egyptias [+ variants]; cf. Puschmann, Nachträge zu Alexander Trallianus..., 62: acanthi Aegyptiae [no variants].

34 + gloss 'm': 'id est spine albe.' (55v).

35 Cf. Mihăileanu, Fragmentele latine..., 165.2: aegyptiae acantis [+ variants]; cf. Puschmann, Nachträge zu Alexander Trallianus..., 96: Aegyptiae acanthi [no variants]. 
The entry in Simon for 'Egyptian acantis', however, refers to 'an eye salve for bathing white spots' - 'leucomata'. Therefore none of these four entries, found in the Philumenus and Philagrius sections of the Latin Alexander - on dysentery and diseases of the intestine, and diseases of the spleen respectively - are Simon's source. Perhaps this example could have been taken from the Greek Therapeutica. A TLG ${ }^{36}$ lemma search of the Greek Therapeutica for ' $\lambda \varepsilon \cup \kappa \omega \mu \alpha$ ' yields three results, ${ }^{37}$ one of which is a recipe for 'white spots/leucomata' (Прòs tò

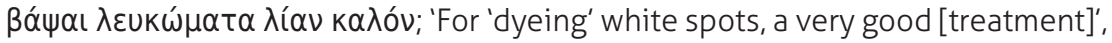

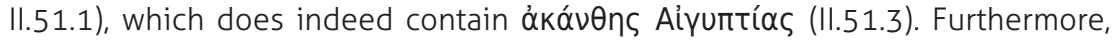
this particular recipe is not found in the Latin Alexander. Has Simon used the Greek Therapeutica for this entry? Further investigation indicates not. Closer examination of the section in the Lyons 1504 edition of the Latin Alexander that is equivalent to this section of the Greek Therapeutica - within the chapters dealing with eye salves ('colliria') - reveals an entry in the Latin Alexander that does correspond to Simon's entry: Book 1, Chapter 101 'Ad tingendas albugines et leucomata tingenda' (Lyons 1504, 21r), and a recipe which contains 'anchotis ${ }^{38}$ egyptie $[\mathrm{sic}]{ }^{\prime} .^{39}$ This particular chapter heading and recipe are not found in the Greek Therapeutica (II.49). Indeed, to date, I have been unable to identify any entries in the Clavis sanationis that are to be found only in Alexander's Greek Therapeutica and not in the Latin Alexander.

One thing that is noticeable from the study of 'Egyptian acantis' is the variation/error in spelling. Indeed, spelling variations/errors abound both between traditions and within traditions. I would like to use Simon's entry for orodes humores - an entry which refers to glosses found in the Latin Alexander - to illustrate the difference between Print A and Print B of the Clavis sanationis:

Orodes humores (Transcript A, 1510, last accessed 13.02.12)

Orodes humores i. serosi aquosi ut Alex. ca. de nausea. Item ca. de scabie vesice. Item ca. de catarticis podagricorum, evocant inquit tenues humores quos greci orodes vocant, interdum oroides invenitur ab oros quod est serum lactis.

Orodes humores (Print B, 1473)

Orodes humores i. serosi aquosi ut Alex ca. de nausea item ca. de catarticis podagriorum [sic] euacuant inquit tenues humores quos gr(_). or(o)des uocant interdum oriodes [sic] inuenitur ab oros quod est serum lactis.

36 Thesaurus Linguae Graecae: http://www.tlg.uci.edu/

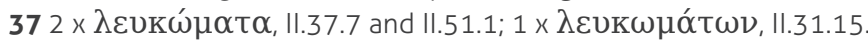

38 + gloss 'a': 'id est spine nigre.' [sic] (21r).

39 'Giptias' in Angers, Bibl. mun. 457 (34ra), using Langslow's transcript. 
Orodes humores, that is serous, aqueous, as in the chapter of Alexander 'On nausea'; likewise in his chapter 'On cathartics for gout'. They evacuate, he says, thin humours, which the Greeks call orodes. Occasionally the spelling oriodes [sic] is found. [The word originates] from oros, which is the whey of milk. (Translating Print B, 1473)

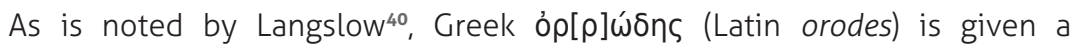
'rudimentary' etymology in the Latin Alexander at 2.42 - this is Simon's chapter 'On nausea' (ca. de nausea), and occurs twice more at $2.249^{41}$ - this is Simon's chapter 'On cathartics for gout' (ca. de catarticis podagri[c]orum).

Note that Print A of the Clavis sanationis also includes the reference 'likewise in the chapter 'On itchiness of the bladder" (Item ca. de scabie vesice), which is also found in Print C (1486). Print B, however, and Manuscript e (Laur. plut. 73, cod. 31) both omit mention of this particular chapter. This is quite possibly a case of saut du même au même - the eye leaping from item to item - however, I suspect the reason might be more complex.

The additional chapter reference found in Print $A$ and Print $C$ is to Book 2, Chapter 198 of the Latin Alexander, which is in a section that is also found in the Greek (II.491.11 ff.). As with the 'Egyptian acantis' example above, there was a brief glimmer that perhaps Simon did have access to and was using a Greek text after all. However, consider the following:

Latin Alexander 2.198: Curatio eiusdem ${ }^{42}$

Est autem confectio medicaminis quod facit ad orodes' [ms. $\mathbf{A}=$ ad sorodis, for Greek

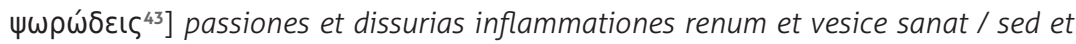
ulcera vesice cum flegmone $f(a) c t a(m)$ sanat. (Lyons 1504, 68v)

There is moreover a preparation of a medicament which is effective against orodes diseases and it cures painful urination [and] inflammations of the kidneys and bladder, but also it cures ulcers of the bladder with inflammation.

40 Langslow, The Latin Alexander Trallianus..., 28 and n. 31

41 'At 2.249, first it is glossed with Latin aquosus, then in the very next sentence it recurs

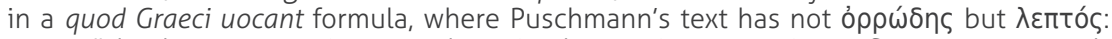
2.249: "dandum est catarticum quod possit educere pingue et spissum flegma et non orode id est aquosum et tenue urinae simile, quemadmodum multi faciunt dantes lacterides et opos titimali et cnidium coccum admiscentes et sic enacuant tenuiores humores quos Graeci orodes

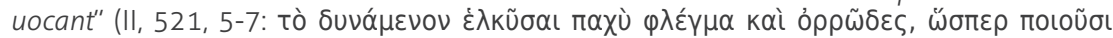

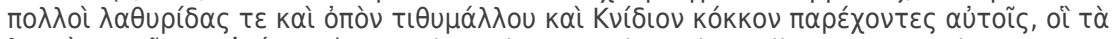

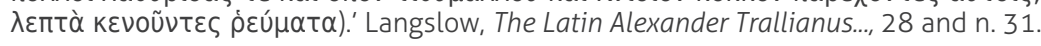

42 Where 2.197 is Si vesica scabiosa sit, the same chapter title is found in $\mathbf{G} \mathbf{2}$ and L1; P1 and [ms.] A have Signa si uesica scabra sit, Ibidem, 251.

43 Puschmann, Alexander von Tralles..., II.493.4 
As can be seen, Lyons 1504 (68v) has 'ad orodes' which even includes the gloss ' $\mathbf{i}$ ': id est serosas seu aquosas (68v). However, the eleventh-century manuscript Angers, Bibl. mun. 457, Langslow's A, has sorodis, a transliteration of Greek $\psi \omega \rho \omega ́ \delta \varepsilon เ \varsigma .44$ Possibly, Simon had a corrupt exemplar with the reading orodes, which is transmitted in Print A and Print $C$ - hence the extra reference and then, possibly, someone has spotted the error with the result that Print $B$ and Manuscript e represent a corrected version.

As another example of spelling errors, consider Simon's entry for embalmata (that is, embammata, 'sauces'):45

Embalmata (Transcript A, 1510, last accessed 12.03.12, entry edited by Barbara Zipser) Embalmata Alexan. ca. de medicinis ad frigidum stomachum, item de reumatismo ventris sunt intinctiones seu salsamenta in quibus morselli intinguntur.

Embasmata AC | Embalmata B e | iunctiones A | intinctiones B e | inunctiones C

According to Alexander, [in the] chapter on medicines for a cold stomach, also [in the chapter] on flux from the belly, embalmata are dips or sauces in which bits of food are dipped.

The second chapter referred to in this entry, 'On flux from the belly' ('de reumatismo ventris'), is to be found in Book 2 of the Latin Alexander, Chapter $79^{46}$ - the 'Philumenus' section:

Latin Alexander 2.79: De reumate ventris Filominis [sic] (Lyons 1504, 47r-48v) 48r: Item embalmata ${ }^{47} 48$ [ms. $\mathbf{A}=$ bamata] hoc modo ad hoc conficiuntur. Cimino cum salis modico et aceto oleo confecto intingitur quod edendum est.

44 LS]: 'of the nature of the itch, scabby'. '[I]n Cassius Felix ... scabiosus is synonymous with Greek psoricus, it means "for treating scabies" ...', Langslow, Medical Latin in the Roman Empire, 344.

45 OLD: embamma, atis (n.) [Gk. ع́ $\mu \beta \alpha \mu \mu \alpha]=$ '[a] sauce or dressing for food, esp. one made with vinegar'.

46 Cf. Puschmann, Nachträge zu Alexander Trallianus..., 26: Item embammata hoc modo ad hoc conficiuntur. Cymino cum sale et modico aceto et oleo confecto intingitur quod edendum est.... Potest autem iuvare et scorpio piscis assatus et cum cymini praedicti embammate datus et ostreae in suis [+ n. 61, re. variant sibi] testis assatae et sumptae. Cf. also Mihăileanu, Fragmentele latine..., 112, 8-16: Item embammata hoc modo ad haec conficiuntur: cimino cum salis modico et aceto et oleo confecto intingitur, quod edendum est.... Potest enim iuvare et scorpion piscis assus [+ variants: assa and assatus] et cum cimini praedicti embammate datus et ostreae in suis testis assatae et assumptae [+ variants: adsumta, sumpta and sumptae].

47 + gloss 'c': 'sunt intinctiones seu salse [sic] in quibus morselli intinguntur. ian(_).' (48r).

48 Cf. Mihăileanu, Fragmentele latine..., 112.8: embammata [no variants]; cf. Puschmann, Nachträge zu Alexander Trallianus..., 26: embammata [no variants]. 
48v: Potestauteminuareetscorpiopiscisassatusetcum ciminipraedictiembalmate ${ }^{4950}$ datus et ostree in suis testis assate et sumpte.

48r: Likewise embalmata are prepared in the following way. What is to be eaten is dipped in cumin prepared in oil with a modicum of salt and uinegar.

48v: Moreover scorpion fish, roasted and given with an embalma of the aforementioned cumin is also able to help, and oysters roasted in their own shells and eaten.

The first chapter, however, 'On medicines for a cold stomach' ('de medicinis ad frigidum stomachum'), is to be found in Book 2, Chapter 46, of the Latin Alexander - not a 'Philumenus' section:

Latin Alexander 2.46: Ad frigidum stomachum embalmata ${ }^{51}$ (Lyons 1504, 40v) [ms. $\mathbf{A}=$ inbamata]

40v: [E]mbalmata ... [for Greek ع́ $\mu \beta \alpha \mu \mu \alpha[$ sic $]]^{52}$

Moreover, it is also found in Book II of the Greek Therapeutica. It is important to note, however, that whereas in the Latin we have embalmata, in the Greek we have ć $_{\beta} \alpha \mu \mu \alpha{ }^{53}$

The following is taken from the entry for embalmata in Simon Online:

... The apparatus of Puschmann's edition does not list any variant readings in this heading. ... Most likely, the error was caused by a Greek manuscript: in Greek minuscule, the letters $\mu$ and $\lambda$ (' $m$ ' and 'l') look very similar and can easily be confused; in majuscule, $M$ looks like a double $\Lambda$. An unknown scribe or translator mistook a ' $m$ ' for an 'l', erroneously assuming the word was in fact derived from $\varepsilon \dot{\varepsilon} \beta \alpha \lambda_{\lambda} \lambda \varepsilon เ \nu$ /emballein/ 'to put inside'. ${ }^{54}$

49 + gloss 'a': 'id est salsamente.' (48v).

50 Cf. Mihăileanu, Fragmentele latine..., 112.15: embammate [no variants]; cf. Puschmann, Nachträge zu Alexander Trallianus..., 26: embammate [no variants].

$\mathbf{5 1}+$ gloss 'f': 'sunt intinctiones seu salsamenta in quibus morselli intinguntur. lan(_).' (40v).

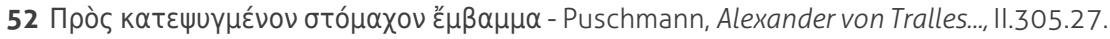

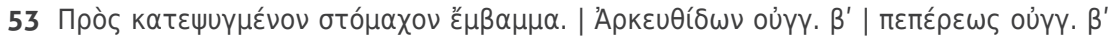

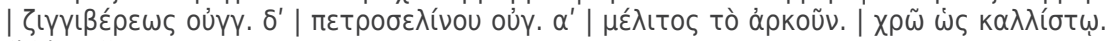
Ibidem, II.305.27-33.

54 embalmata: Simon Online, last accessed 12.03.12, entry edited by Barbara Zipser 
As can be seen in the three entries from the Clavis sanationis discussed in detail above - acantis egyptia, embalmata (that is, embammata) and orodes humores - spelling errors/variants can be very misleading. They can also be very useful. Indeed, a close study of these errors/variants, as well as additions and omissions, found when comparing Simon's Clavis sanationis with the Latin Alexander might make it possible to narrow down Simon's manuscript source or sources, and potentially assign them to a particular branch of Langslow's stemma (given in Appendix 2, and reproduced with the kind permission of David Langslow). For example, the fact that Simon often quotes from those sections of the Latin Alexander that we know are in fact interpolations from the translated works of Philumenus and Philagrius (Appendices 3 and 4), without referring to Philagrius or Philumenus by name, is potentially useful.

In the Lyons 1504 edition of the Latin Alexander, Chapter 2.79, 'On flux from the belly', is clearly headed 'On flux from the belly, of Philumenus' (De reumate ventris Filominis [sic], 47r), as indeed it is in the manuscripts $\mathbf{G} \mathbf{2}, \mathbf{L} \mathbf{1}, \mathbf{P} \mathbf{1}$ (De reuma ...) and A. ${ }^{55}$ Furthermore, a later chapter, Chapter 2.81, 'Signs of dysentery', is also identified as by Philumenus (Signa dissinterice passionis Philomini) in Lyons 1504 (49r), and in the manuscripts G2, L1 and A, and although Philumenus is not mentioned in the title here in $\mathbf{P 1}$, the chapter begins with 'Of Philumenus' (Filomini). ${ }^{56}$ The same is seen in the heading for Chapter 2.99, 'On bowel diseases, of Philumenus' (De ciliacis [i.e., coeliacis] Philomini), with the title in Lyons 1504 (52r) and the manuscripts $\mathbf{G} \mathbf{2}$, L1 and $\mathbf{A}$ all mentioning Philumenus, but with the chapter in $\mathbf{P} \mathbf{1}$ beginning, this time with an error, 'Flaminum' $[\mathrm{sic}] .^{57}$

Likewise in Lyons 1504, Chapter 2.104 is clearly headed 'Philagrius on the spleen' (Ad splenem Philagrius, 53r), as indeed it is in the manuscripts $\mathbf{G 2 , ~} \mathbf{L 1}$ and $\mathbf{A}$; here $\mathbf{P} \mathbf{1}$ has no title. ${ }^{58}$ Furthermore, the chapter heading of 2.151 on dropsy, immediately following the end of the Philagrius section, (Causa que est ydropicie Alexandri, Lyons 1504, 59r), is explicitly assigned to Alexander, clearly signalling the return to his work. This explicit reference to Alexander is also seen in the equivalent chapter headings in $\mathbf{G} \mathbf{2}, \mathbf{L} \mathbf{1}, \mathbf{P} \mathbf{1}$ and $\mathbf{A} .^{59}$

Given that Simon's entries contain no reference to Philumenus or Philagrius, one does have to wonder whether Simon's exemplar(s) contained the overt references to Philumenus and Philagrius.

55 Langslow, The Latin Alexander Trallianus..., 246.

56 Ibidem, 246.

57 Ibidem.

58 Ibidem.

59 P1: 'Causa aedropiciae alexandriae'; [ms.] A: 'Causa ydropicie Alexandri' - Ibidem, 249. 
Consider again the excerpt taken from the moderately lengthy entry for sauich and the reference to the fact that in books translated from the Greek, 'sauich' is written 'polenta':

Sauich (Print B, 1473)

... notandum tamen quod ubicumque habetur in liberis [sic] de arabico translatis sauich apud Dia. et Alex. et Paul(_) et alios de greco translatos habetur polenta quare secudum [sic] idem uidetur apud grecos vero uocatur alfita ut patet per Gal(_). ca. de alfitis in libro de alimentis item Ste. in sinonimis dicit quod alfiton est sauich.

... Note, however, that everywhere it is written in books translated from Arabic [it is] sauich; in the writings of Dioscorides and Alexander and Paul and others translated from the Greek, it is written polenta, for which reason we may assume they are synonyms. Among the Greeks, indeed, it is called alphita, as is revealed through Galen in the chapter on alphita in his book On foods. Likewise Stephanus in his Synonyms says that alphita is sauich.

Opsomer ${ }^{60}$ records just one occurrence of polenta in the Latin Alexander, in Book 3, Chapter 66, Lixoperita epithimata et embroce et emplastra febrientibus Martyrii medicici (Lyons 1504, 92v-93r):

93r: Item embroca ex alica ${ }^{62}$ aut oxilapatos ${ }^{63}$ autem bene facit et succus si de polenta .i. alfita ${ }^{64}$ tenui modicum ei misces infuso duplicato panno molli.

If Simon's reference to 'Alexander' and 'polenta' does in fact refer to Book 3 , Chapter 66, it is referring to a section in the Latin Alexander that is not found in many of the Latin manuscripts, ${ }^{65}$ and has no equivalent in Puschmann's Greek text. ${ }^{66} 6768$ Moreover, even where this chapter is found in the Latin manuscripts, it is not always present in its entirety.

60 Carmelia Opsomer, Index de la pharmacopée...

61 See Langslow, The Latin Alexander Trallianus..., 262 n. 110 for variants.

62 + gloss 'e': ' alica est genus frumenti quidam speltam putant.' (93r).

63 + gloss 'f': 'id est acetosa herba.' (93r).

64 + gloss ' $\mathrm{g}$ ': 'id est farina ordei.' (93r).

65 Langslow, The Latin Alexander Trallianus..., 59.

66 Puschmann, Alexander von Tralles...

67 '... 3.66 ... is not in the Greek Alexander as we have it, and ... could be an addition to the original version of the Latin Alexander ...' - Langslow, The Latin Alexander Trallianus..., 58.

68 However, compare the Latin found at Lyons 1504, 93r (Item embroca ex alica aut oxilapatos autem bene facit et succus si de polenta i. alfita tenui modicum ei misces infuso 
The whole chapter is missing from $\mathbf{P 1} \mathbf{1}, \mathbf{O}, \mathbf{D}, \mathbf{O x}, \mathbf{G e}, \mathbf{M a}, \mathbf{P 2}, \mathbf{L 2}$ and $\mathbf{B} .{ }^{69}$ It is present in M, G1, Mu, C, P3, G2, L1 and, of course, Lyons 1504 (Langslow's ed.). ${ }^{70}$ Of itself, this is not proof that Simon used this manuscript or that manuscript, not least because I am not absolutely sure that this chapter is the source of Simon's comment on polenta.

Consider now three entries in the Clavis sanationis - amitrocera, centron and acros - all of which occur in the chapters on coughing at the beginning of Book 2 of the Latin Alexander; chapters, moreover, which are to be found in Langslow's published edition with a full apparatus. ${ }^{71}$

duplicato panno molli) with the following three extracts of Greek texts taken from Galen, Oribasius and Aëtius: [1.] Galen (De methodo medendi 10.9, C. G. Kühn, Claudii Galeni opera omnia, vol. 10 (repr. 1965, Hildesheim: Olms, Leipzig: Knobloch, 1825)):

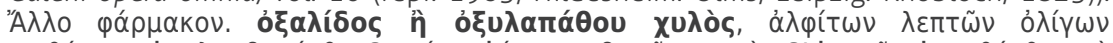

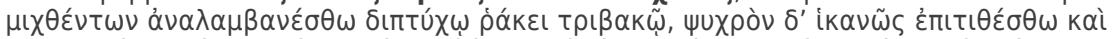

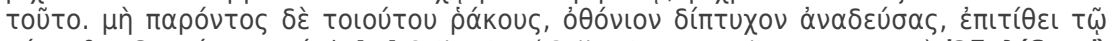

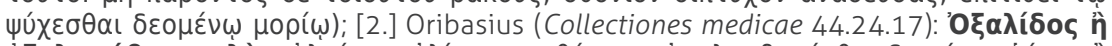

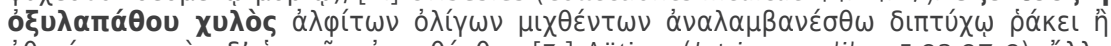

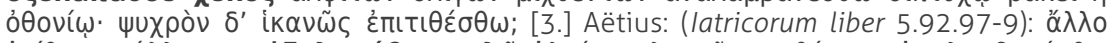

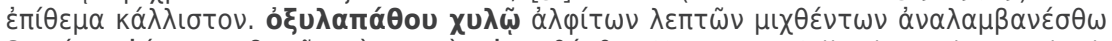

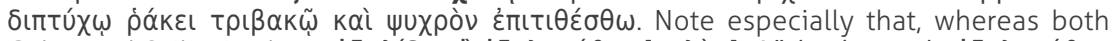

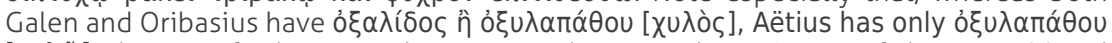
$[\chi \cup \lambda \tilde{\omega}]$. There are further textual resonances between the Latin text of chapter 3.66 and the Greek texts of Galen, Oribasius and Aëtius. Indeed, elsewhere in chapter 3.66 we find overt references to both Galen ('Emplastrum Galieni ...', 92v) and Oribasius ('Item lixoperitum Oribasii ...', 93r). Furthermore, the 'lixoperitum Oribasii' found in 3.66 of the Latin Alexander is strikingly similar to the 'lyxypyreton [sic] ... mirabilem' of the Latin Oribasius at Synopsis 3.60 (see Ulco Cats Bussemaker, Charles Daremberg and Auguste Molinier, Oeuvres d'Oribase, 6 vols. (Paris: Imprimerie Nationale, 1851-76), 5.863), which itself is to be found in the Greek Oribasius (Johann Raeder, Oribasii synopsis ad Eustathium et libri ad Eunapium [Corpus medicorum Graecorum 6.3] (repr. 1964, Amsterdam: A. M. Hakkert, Leipzig: Teubner, 1926), 3.60.

69 See Langslow, The Latin Alexander Trallianus..., 40 (for A: 'text breaking off abruptly in 3.34'); 41 (for B: 'just less than half a page of the start of Book 3'); 42 (for $\mathbf{D}$ : 'text of Book 3 , to end of 3.65'); 43 (for Ge: 'text of 3.1-65'); 45 (for L2: 'unnumbered chapters ending with the end of 3.65' and $\mathbf{M a}$ ' 'text of 3.1-65'); 48 (for $\mathbf{0}$ : 'text, breaking off abruptly after (3.13 ad fin.) ...'); 49 (for Ox: 'expl. 119r (end of 3.65) ...'); 50 (for P1: 'text of Book 3, breaking off at 3.63 ...' and P2: 'text of Book 3, ending with 3.65').

70 See Langslow, The Latin Alexander Trallianus..., 42 (for C: 'text of Book 3, including all but the very last recipe of 3.66'); 44 (for $\mathbf{G 1}$ : 'text of Book 3, including all but the very last recipe of 3.66', G2: 'Book 3 ... 66 chapters' and L1: 'Book 3 ... 66 ... chapters'); 46 (for M: 'Book 3 ending with the penultimate recipe of 3.66 (minus the last three words)') and 47 (for Mu: 'text of Book 3 to the very end of 3.66'); 51 (for P3: 'text of Book 3, breaking off without an Explicit after only 8 lines of 3.66 ...').

71 Langslow, The Latin Alexander Trallianus..., 175-229. 
First, amitrocera, which has the following entry in Simon:

Amitrocera (Transcript A, 1510, last accessed 10.03.12)

Amitrocera .g. facilis ad cognoscendum. Alexan. ca. de tussi materialis autem et cetera.

Amitrocera (Print B, 1473)

Amicrotera [sic] gr(_). facilis ad cognoscendum Alex. capitulo de tussi materialis et cetera.

The following text, relevant apparatus and translation of the Latin Alexander is taken from Langslow: ${ }^{72} 73$

2.4.2 Differunt igitur quod magis operativae habent manifestas significationes, materiales autem [si accesserit tussis] amitroteras \{for Greek $\boldsymbol{\alpha} \boldsymbol{\mu} \boldsymbol{0} \boldsymbol{\delta} \boldsymbol{\rho} \boldsymbol{\tau} \tau \boldsymbol{\varepsilon} \boldsymbol{\rho} \boldsymbol{\alpha}^{74}{ }_{,}{ }^{75}$ et non oportet $<\mathrm{t}>\mathrm{alia}^{76}$ iterum dicere.

amitroteras scripsimus (fort. cf. a materia est $\mathbf{M}$ )] -a plerique (amet- $\mathbf{P} \mathbf{1}$ amyt$\mathbf{P 2}$ amicr- $\mathbf{G} \mathbf{L} \mathbf{L}$ ) amitro terea $\mathbf{0}$ amicio tera $\mathbf{e d .} .^{77}$ amitrota $\mathbf{G e}$ a materia $\mathbf{M}$ om. Mu (post a. habent est M D P3 add. $\mathbf{m} \mathbf{3}) \mathbf{G} \mathbf{2}$

72 See Langslow, The Latin Alexander Trallianus..., 200-3. Where $\{. .$.$\} indicates additional$ material.

73 Cf. Lyons 1504, 32v: Differunt igitur quod operatiue [+ gloss 'g': id est actine qualitates] magis manifestas habent significationes. Cap(_). 5: De tussi si ex humoribus fiat. [M]aterialis autem si accesserit tussis amicio [+ gloss ' $h$ ': id est facilis ad cognoscendum. Ian(_). ] tera [+ gloss 'i': est [sic]] et non oportet iterum taliter dici [+ gloss ' $k$ ': .s. signa quibus cognoscatur si materialis est]. Langslow notes that, in an 'apparent corruption common to all the Latin manuscripts', 'si accesserit tussis' has been added 'in an effort to make sense of a Latin text rendered unintelligible by the transposition of the section-heading 2.5.t. De tusse si ex humoribus fiat (itself not in the Greek text either)', Langslow, The Latin Alexander Trallianus..., 104.

74 Puschmann, Alexander von Tralles..., Il.149.13

75 Langslow, The Latin Alexander Trallianus..., 117: 'The Latin tradition offers various explanatory notes to Greek $\alpha \mu \nu \delta \rho o ́ t \varepsilon \rho \alpha$, among which P2 and B alone have leuior ad curandum, and G1 alone the very similar leuis ad curandum. [+ n. 18: 'cf. levior facilior

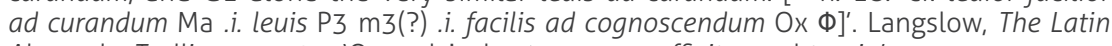
Alexander Trallianus..., 129: 'Ox and $\Phi$ also transpose efficitur and tussis.'

76 Where the reading '<t>alia' is to be credited to Cloudy Fischer.

77 Where Langslow's ed. $=$ Lyons 1504. 
They differ in that the active tend rather to have clear signs, while the material ones have more indistinct signs. And it is not necessary to say this again.

The following is Langslow's note on amitroteras: ${ }^{78}$

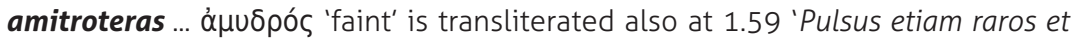

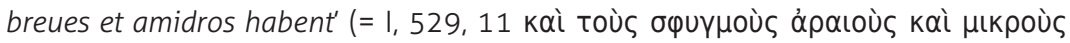

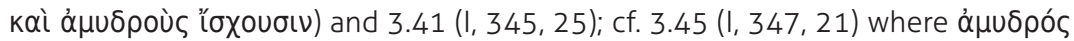
is confused with ó $\mu \varepsilon \tau \rho \circ \varsigma$ and translated absque mensura. That the word was less than familiar is seen clearly at 3.48 'pulsus ... paruus autem et amidros in ethica febre', where the Latin version adds the note: 'Amidros autem pulsus dicitur defectus, qui solutam habet uirtutem et percussionem facit imbecillem'. (The marginal gloss at this point ... reads '.i. imbecillis seu debilis. Gal. in lib. de differentiis febrium'.) ${ }^{79}$

Of interest here are those manuscripts that do not include amitrocera regardless of spelling - that is: $\mathbf{M}, \mathbf{M u}$ and $\mathbf{G e}$.

Secondly centron, which has the following entry in Simon:

Centron (Transcript A, 1510, last accessed 10.03.12)

Centron Alex. ca. tussi exponunt quidam punctiones.

Centron (Print B, 1473)

Ceneron [sic] Alexan. ca. de tussi exponit quedam [sic] punctiones.

Again, the following text, relevant apparatus and translation is taken from Langslow: 80

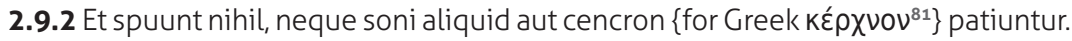
Neque enim contingere poterit [nisi] ex indigesto et necdum permixto fymate.

78 Langslow, The Latin Alexander Trallianus..., 201 n.85.

79 Cf. Simon (Transcript A, 1510, last accessed 12.03.12) 'Amidros: Amidros pulsus Alex. capitulo de litargia exponitur a .G. liber de doctrina pulsuum quod est imbecillis seu debilis. Sed liber de doctrina greca amidron obscurum minus apparens.'

80 Langslow, The Latin Alexander Trallianus..., 216-17. Cf. Lyons 1504, 33r: Et spuunt nihil: neque soni aliquid aut centron [sic + gloss ' $h$ ': centron exponunt quidam punctiones] patiuntur. Neque enim contingere [+ gloss ' 'i': tussis .s. vel centron] potest nisi ex indigestione et nedum [sic] permixto fimate [+ gloss 'k': id est inflato(_)e turge(_)te vel pusculosa vel tuberculo. Ian(_).].

81 Puschmann, Alexander von Tralles..., II.153.2 
cencron P3] concron $\mathbf{M a}$ centron cett. cetron $\mathbf{M u}$ cendron $\mathbf{O}$ centro $\mathbf{A}$ centrum $\mathbf{P} \mathbf{1}$ tenorum $\mathbf{M}$ ad hoc uerbum habent i. punccionem $\mathbf{M a}$.i. punctionem $\mathbf{D}$ centron exponunt quidam punctiones $\Phi$

And they spit nothing up, nor do they suffer any noise (in the ears) or hoarseness, for it cannot possibly occur while the tumour is immature and not yet thoroughly mixed.

Langslow's note on cencron is as follows:

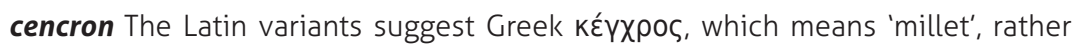
than képXvos 'roughness, hoarseness', which is very suitably rendered with raucor in the very next section (2.10.1). LSJ, s. vV., suggests some confusion between the

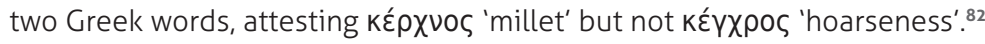

What is important in this example are the glosses added to $\mathbf{M a}, \mathbf{D}$ and $\boldsymbol{\Phi}$, given that Simon Print A has 'exponunt quidam punctiones' and Simon Print B has 'exponit quedam [sic] punctiones', where punctiones are 'stabbing pains'.

Thirdly, Simon's entry for acros:

Acros (Transcript A, 1510, last accessed 15.03.12)

Acros .i. acredo Alex. capitulo de tussi, quando aut de subito et cetera.

Acros (Print B, 1473)

Acros i. acredo Alex. capitulo de tussi quando autem subito et cetera.

Once again, the following text and relevant apparatus is taken from Langslow: ${ }^{83}$

2.10.1 Quando autem desubito qui laborant sentiunt coangustata praecordia se habere et absque febribus molestari et siti multa, sed habent etiam quendam raucorem \{for Greek képXvov $\left.{ }^{84}\right\}$ cum tusse ...

82 Langslow, The Latin Alexander Trallianus..., 216 n. 157.

83 Langslow, The Latin Alexander Trallianus..., 218-19. Cf. Lyons 1504, 33r: [A]liquando autem de subito qui laborant sentiunt $p$ (rae)angustata [sic] p(rae)cordia se habere et absque febribus molestari: et sitis multa sit / et habent etiam quandam [sic] rancorem [sic] et acrorem cum tusse...

84 Puschmann, Alexander von Tralles..., II.153.9. 
raucorem $\mathbf{O}$ L2 P3 (ruccorem P1 rugura $\mathbf{M}$ )] ranc(h)orem cett. |ante cum habent et acrorem P3 D 0x Ge G2 ed. acrorem Ma

When the patients suddenly feel that the chest is constricted and troubled (although) without fever and without great thirst, but they have also a certain hoarseness with the cough ...

Here, it is the addition of et acrorem before raucorem, seen in the manuscripts P3, D, 0x, Ge, G2 and Lyons 1504 (Langslow's ed.), and acrorem before raucorem in the manuscript Ma which is interesting. acror is 'a bitter taste in the mouth', hence Simon's id est acredo, where acredo is 'a sharp or pungent taste'. There is no equivalent to this in Puschmann's Greek text.85

By collecting further examples, more evidence could be found that perhaps might indeed help locate Simon's source or sources on Langslow's stemma. So far, based on the evidence of amitrocera, centron and acros, $\Phi$ has 'three ticks', but the tradition above is very complex and therefore care must be taken before positing any firm conclusions. However, the shared innovations between both Simon and $\Phi$ are striking. ${ }^{86}$

In this paper, I hope to have showed that Simon, when compiling his Clavis sanationis, used the Latin Alexander. I have also made a tentative first attempt to locate Simon's exemplar(s) on David Langslow's stemma. I would like to end with a brief comment on the Lyons 1504 edition of the Latin Alexander, the Practica Alexandri yatros greci cum expositione glose interlinearis lacobi de partibus et lanuensis in margine posite - to give it its full title - edited by Fr. Fradin. The 'lacobus de partibus' of the title is Jacques Despars (c. 1380-1458) ${ }^{87}$ and the 'Ianuensis' is '[Simonis] lanuensis' - Simon of Genoa. The Lyons 1504 edition includes a vast number of glosses that represent the scholarly endeavours of both Jacques Despars and Simon of Genoa (throughout this paper, whenever I have quoted from the Lyons 1504 edition of the Latin Alexander, I have included a reference to any glosses in the footnotes). In conclusion, therefore, not only is the Latin Alexander a 'source text' for Simon's Clavis sanationis, but also the entries in the Clavis sanationis that are taken from the Latin Alexander are of great importance for any consideration of the Lyons 1504 printed edition, as well as the extremely complex later manuscript tradition of the Latin Alexander.

85 Puschmann, Alexander von Tralles....

86 For the ' $\Phi$-recension' and 'sources of $\Phi$ ', see Langslow, The Latin Alexander Trallianus..., 126-30.

87 For Jacques Despars, see Thomas Glick, Steven Livesey, and Wallis (Eds.), Medieval science, technology and medicine: An encyclopedia. (New York, NY: Routledge, 2005), 151-2; Langslow, The Latin Alexander Trallianus...,10 and n. 77. 


\section{Bibliography}

\section{Primary sources, early printed books and manuscripts:}

Alexander Trallianus: Practica Alexandri yatros greci cum expositione glose interlinearis lacobi de partibus et lanuensis in margine posite, edited by Fr. Fradin. Lyons 1504.

Simon Print $A=$ Simonis Januensis opusculum cui nomen Clavis sanationis simplicia medicinalia latina greca at arabica ordine alphabetico mirifice elucidans recognitum ac mendis purgatum et quotationibus Plinii maxime: ac aliorum in marginibus ornatum. Venice: For heirs of O. Scotus by B. Locatellus, 1510.

Simon Print $B=$ Synonyma Simonis Genuensis, opus impressum per Antonium Zarotum parmensem. Milano 1473.

Simon Print $\mathrm{C}=$ Simon lanuensis Clavis sanationis, Venetiis per Gulielmum de Tridino ex Monteserato, 1486.

Simon Manuscript e $=$ Biblioteca Medicea Laurenziana Plut. 73, cod. 31, f. 6r-110r ff.

\section{Primary sources, other:}

Bussemaker, Ulco Cats, Charles Daremberg and Auguste Molinier. Oeuvres d'Oribase, 6 vols. Paris: Imprimerie Nationale, 1851-1876.

Heiberg, Johan Ludvig. Pauli Aeginetae libri tertii interpretatio latina antiqua. Leipzig: Teubner, 1912. 
Kühn, C. G. Claudii Galeni opera omnia, vol. 10, repr. 1965, Hildesheim: Olms. Leipzig: Knobloch, 1825.

Langslow, David R. "Chapter 5: An edition of the Latin Alexander on coughing." In idem, The Latin Alexander Trallianus: The text and transmission of a Late Latin medical book. 175-229. London: Society for the Promotion of Roman Studies, 2006.

Masullo, Rita. Filagrio: Frammenti. Naples: Bibliopolis, 1999.

Mihăileanu, Peter. Fragmentele latine ale lui Philumenus şi Philagrius. Bucharest: Institutul de Arte Grafice 'Carol Göbl', 1910.

Olivieri, Alessandro. Aëtii Amideni libri medicinales v-viii [Corpus medicorum Graecorum 8.2]. Berlin: Akademie-Verlag, 1950.

Puschmann, Theodor. Alexander von Tralles. Original-Text und Übersetzung nebst einer einleitenden Abhandlung. Ein Beitrag zur Geschichte der Medicin, 2 vols, repr. 1963, Amsterdam: A. M. Hakkert. Vienna: W. Braumüller, 1878-1879.

- Nachträge zu Alexander Trallianus: Fragmente aus Philumenus und Philagrius, repr. 1963, Amsterdam: A. M. Hakkert. Berlin: S. Calvary and Co., 1886.

Raeder, Johann. Oribasii synopsis ad Eustathium et libri ad Eunapium [Corpus medicorum Graecorum 6.3]. repr. 1964, Amsterdam: A. M. Hakkert. Leipzig: Teubner, 1926.

- Oribasii collectionum medicarum reliquiae, vols 1-4 [Corpus medicorum Graecorum 6.1.1-6.2.2]. Leipzig: Teubner, 1928-1933.

\section{Secondary sources:}

Beck, Lily Y. Pedanius Dioscorides of Anazarbus: De materia medica (2nd edn). Hildesheim, Zürich and New York, NY: Olms-Weidmann, 2011.

Glick, Thomas F., Steven John Livesey and Faith Wallis (Eds.). Medieval science, technology and medicine: An encyclopedia. New York, NY: Routledge, 2005.

Jacques, Jean-Marie. "Philoumenos of Alexandria (150 - 190 CE)." In Paul T. Keyser and Georgia L. Irby-Massie (Eds.), The encyclopedia of ancient natural 
scientists. 661-662. London and New York, NY: Routledge, 2008.

Langslow, David R. Medical Latin in the Roman Empire. Oxford and New York, NY: Oxford University Press, 2000.

- The Latin Alexander Trallianus: The text and transmission of a Late Latin medical book. London: Society for the Promotion of Roman Studies, 2006.

Opsomer, Carmelia. Index de la pharmacopée du ler au Xe siècle, 2 vols. Hildesheim, Zürich, and New York, NY: Olms-Weidmann, 1989.

Pormann, Peter E. "Paulos of Aigina (ca 630 - 670 CE?)." In Paul T. Keyser and Georgia L. Irby-Massie (Eds.), The encyclopedia of ancient natural scientists. 625. London and New York, NY: Routledge, 2008.

Scarborough, John. "Philagrios of Ėpeiros (300 - 340 CE)." In Paul T. Keyser and Georgia L. Irby-Massie (Eds.), The encyclopedia of ancient natural scientists. 643644. London and New York, NY: Routledge, 2008.

Zipser, Barbara. "Die Therapeutica des Alexander Trallianus: Ein medizinisches Handbuch und seine Überlieferung." In Rosa Marie Piccione and Matthias Perkams (Eds.), Selecta Colligere, II. Beiträge zur Methodik des Sammelns von Texten in der Spätantike und in Byzanz (Collana Hellenika). 211-234. Alessandria: Edizioni dell'Orso, 2005. 


\section{Appendix 1}

\section{Manuscripts containing the Latin Alexander ${ }^{88}$}

\section{Complete copies}

P1 Paris, BN lat. 9332 (early $9^{\text {th }}$ cent.)

M Montecassino, Archivio della Badia 97 (early 10 ${ }^{\text {th }}$ cent.)

A Angers, Bibl. mun. 457 (11 $1^{\text {th }}$ cent.)

0 Orléans, Bibl. mun. 283 (end $11^{\text {th }}$ cent.)

D Durham, Cathedral C. 4.11 (end $12^{\text {th }}$ cent.)

G1 Glasgow, University Library Hunter $435\left(12^{\text {th }}-13^{\text {th }}\right.$ cent.)

Mu Munich, BSB Clm 344 (12 $2^{\text {th }}-13^{\text {th }}$ cent.)

Ox Oxford, Pembroke College $8\left(12^{\text {th }}-13^{\text {th }}\right.$ cent.)

C Cambridge, Gonville \& Caius College 400 (early $13^{\text {th }}$ cent.)

Ge Geneva, Bibl. publ. et univ. 78 ( $13^{\text {th }}$ cent.)

Ma Madrid, BN 1049 (13 $3^{\text {th }}$ cent.)

P2 Paris, BNF lat. 6881 (13 ${ }^{\text {th }}$ cent.)

P3 Paris, BNF lat. 6882 (13 $3^{\text {th }}$ cent.)

L2 London, BL Royal 12. B. XVI (late $13^{\text {th }}$ cent.)

B Brussels, KBR 10869 (14 ${ }^{\text {th }}$ cent.)

G2 Glasgow, University Library General 1228 (second half $15^{\text {th }}$ cent.)

L1 London, BL Harley 4914 (16 ${ }^{\text {th }}$ cent.)

Complete copies not seen by Langslow (before 2006)

Oxford, Bodl. 524 (12 ${ }^{\text {th }}$ cent)

Vatican City, BAV Pal. lat. 1209 (13 $3^{\text {th }}$ cent.)

Lost copies

Ch Chartres, Bibl. mun. 342 ( $12^{\text {th }}$ cent.) - 'surviving only in a few photographs' [Metz Metz, Bibl. de la Ville ms. 278 (early 13 ${ }^{\text {th }}$ cent.) - 'no reproductions of, or studies bearing on it are known' 89

88 Langslow, The Latin Alexander Trallianus..., 38

89 Langslow, The Latin Alexander Trallianus..., 52-3 and n. 48 


\section{Appendix 2}

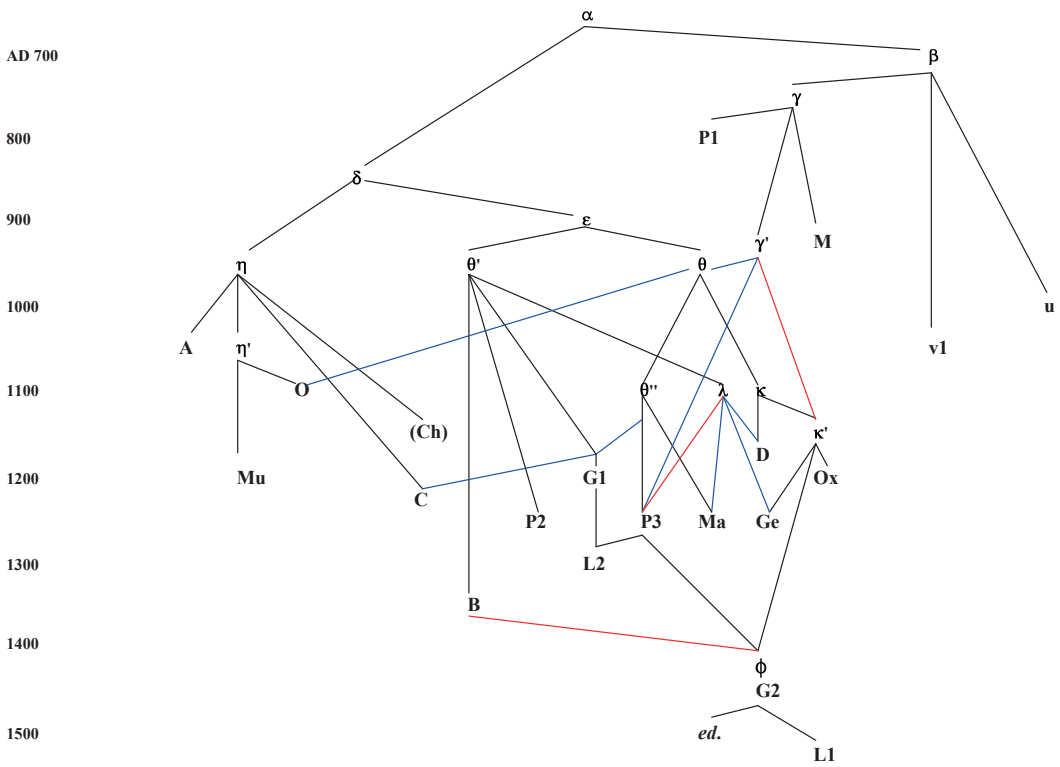

Figure 1. Stemma showing the relations between the mainstream manuscripts of the Latin Alexander (and $\mathrm{v} 1$ and $\mathrm{u}$ of the secondary tradition). (Probable or certain use of an accessory model is indicated in [blue], possible but uncertain use in [red]. The dating of lost copies is approximate only.). Langslow, The Latin Alexander Trallianus..., Plate XII. Stemma reproduced with the kind permission of David Langslow. 


\title{
Appendix 3
}

Philumenus $^{90}$ (Transcript A, 1510, accessed from Simon Online 10.03.12, unless stated otherwise)

\section{Acantis egyptia (Transcript A, 1510, last accessed 12.03.12)}

A Acantis egyptia invenitur in practica Alexandri in confectione collirii ad tingenda leucemata puto quod sit idem quod achantis arabica.

B Achantis egiptiaca [sic] inuenitur in pratica [sic] Ale. in confectione colirii [sic] ad tingenda leucomata puto quod sit idem quod achantis ara.

2.79 De reumate ventris Filominis [sic] (Lyons 1504, 47r-48v)

48r: acantis $^{91}$ egiptiace $\left[\right.$ sic ${ }^{92}$

2.80 De dissinteria reumatica (Lyons 1504, 48v-49r)

$48 \mathrm{v}$ : achantem ${ }^{93}$ egyptiam $^{94}$

2.98 Enema ad dissintericos et dolores nimios vel inflammationes (Lyons 1504, 51v-52r)

52r: achanthos ${ }^{95}$ egyptie ${ }^{96}$

[Philagrius] 2.123 De fomentationibus (Lyons 1504, 55r-55v)

55v: egyptie ${ }^{97}$ acautis [sic] ${ }^{98}$

\section{Epythyma elidion}

\author{
A Epythyma elidion Alex. ca. de reumate ventris. \\ B Epithima clidion [sic] Alex. capitulo de reumate uentris. \\ 2.79 De reumate ventris Filominis [sic] (Lyons 1504, 47r-48v) \\ 47v: ... Epithima dydyon ${ }^{99}$ [sic] hoc modo conficitur. ...
}

90 2.79-103: Lyons 1504, 47r-53r.

91 + gloss 'l': 'id est spine albe.' (48r).

92 Cf. Mihăileanu, Fragmentele latine..., 110.7: acantis aegyptias [+ variants]; cf. Puschmann, Nachträge zu Alexander Trallianus..., 24: acanthi Aegyptiacae [no variants].

93 + gloss 'c': 'id est spinam al(_)s.' (48v).

94 Cf. Mihăileanu, Fragmentele latine..., 116.10: acantem egyptiam [+ variants]; cf. Puschmann, Nachträge zu Alexander Trallianus..., 32: acanthum Aegyptiacam [no variants].

95 + gloss ' $z$ ': 'id est spine albe.' (52r).

96 Cf. Mihăileanu, Fragmentele latine..., 139.11: acantis egyptias [+ variants]; cf. Puschmann, Nachträge zu Alexander Trallianus..., 62: acanthi Aegyptiae [no variants].

97 + gloss 'm': 'id est spine albe.' (55v).

98 Cf. Mihăileanu, Fragmentele latine..., 165.2: aegyptiae acantis [+ variants]; cf. Puschmann, Nachträge zu Alexander Trallianus..., 96: Aegyptiae acanthi [no variants].

99 Cf. Mihăileanu, Fragmentele latine..., 108.4: Epitima clidion [+ variants]; cf. Puschmann, Nachträge zu Alexander Trallianus..., 22): Epithema clidion [no variants]. 


\section{Ciliaca}

A Ciliaca passio est fluxus ventris vitio stomachi nam.g. kiliam ventrem vocant ut in passionario suo ca. et est kilia fundus stomachi proprie. Item Alex. fit aut ex indigestione ventris defecti, liber de doctrina greca kilia alvus uterus venter.

B Ciliaca passio est fluxus uentris uitio sto(_)a. nam gre. kiliam uentrem uocant ut in pasionario [sic] suo ca. et est kilia fundus sto(_)a. proprie. Item Alexan. fit autem ex indigestione uentris defecti: liber de doctrina gr(_). kilia koria aluus uter [sic] uenter.

2.99 De ciliacis Philomini (Lyons 1504, 52r-52v)

[C] iliace ${ }^{100}$ passiones et indigestiones ex indigestione [sic] ipsius ventris fiunt eo quod non p(otes)t ex ipsa defectione ministrare corpori nutrimentum.... ${ }^{101}$

Embalmata (Transcript A, 1510, last accessed 12.03.12)

A Embalmata Alexan. ca. de medicinis ad frigidum stomachum, item de reumatismo ventris sunt intinctiones seu salsamenta in quibus morselli intinguntur.

Embasmata AC | Embalmata B e | iunctiones A | intinctiones B e | inunctiones C

[Not 'Philumenus section'] 2.46 Ad frigidum stomachum embalmata ${ }^{102}$ (Lyons 1504, 40v) [ms. A = inbamata]

40v: [E]mbalmata ... [for Greek ह̌ $\mu \beta \alpha \mu \mu \alpha\left[\right.$ sic] ${ }^{103}$

2.79 De reumate ventris Filominis [sic] (Lyons 1504, 47r-48v)

48r: Item embalmata ${ }^{104} 105$ [ms. A = bamata] hoc modo ad hoc conficiuntur. Cimino cum salis modico et aceto oleo confecto intingitur quod edendum est.

48v: Potest autem inuare et scorpio piscis assatus et cum cimini praedicti embalmate ${ }^{106} 107$ datus et ostree in suis testis assate et sumpte.

$100+$ gloss 'l': 'est fluxus ventris vitio stamachi [sic].' (52r).

101 Cf. Mihăileanu, Fragmentele latine..., 140.20-141.1: 'Ciliacae passiones ex indigestione ipsius ventris fiunt eo, quod ipse defectum patitur et non potest ex ipsa [141] defectione ministrare corpori nutrimenta.' [+ variants]. Cf. Puschmann, Nachträge zu Alexander Trallianus..., 64: 'Coeliacae passiones ex indigestione ipsius ventris fiunt eo quod non potest ex ipsa defectione ministrare corpori nutrimentum.' [+ variants].

102 + gloss 'f': 'sunt intinctiones seu salsamenta in quibus morselli intinguntur. lan(_).' (40v).

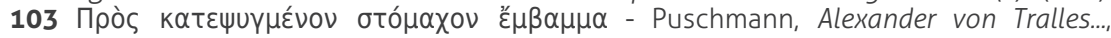
II.305.27.

104 + gloss 'c': 'sunt intinctiones seu salse [sic] in quibus morselli intinguntur. ian(_).' (48r).

105 Cf. Mihăileanu, Fragmentele latine..., 112.8: embammata [no variants]; cf. Puschmann, Nachträge zu Alexander Trallianus..., 26: embammata [no variants].

$106+$ gloss 'a': 'id est salsamente.' (48v).

107 Cf. Mihăileanu, Fragmentele latine..., 112.15: embammate [no variants]; cf. Puschmann, Nachträge zu Alexander Trallianus..., 26: embammate[no variants] 


\section{Appendix 4}

Philagrius $^{108}$ (All Transcript A, 1510, last accessed from Simon Online 10.03.12)

Acantis egyptia: please see Appendix 3, Philumenus

\section{Arthomeli}

A $\quad$ Arthomeli.g. panis cum melle factus Alex. ca. de cathaplasmatibus ad splenem cum ergo cognoveris et cetera.

B

Artomeli gr(_). panis cum melle factus Ale. capitulo de cataplasmatibus ad splenem cum ergo cognoueris et cetera.

2.129 De cathaplasmate faciendo (Lyons 1504, 56r-56v)

... Sepius autem sicut nouisti artomelli ${ }^{109} 110$ usi sumus cum aqua....

\section{Cinarum}

A Cinarum .g. Alex. ca. de cura calide et humide distemperantie splenis.

B Cinaron [sic] g(_). Alexan. ca. de cura ca. de. [sic] et hu[l]de distemperatione splenis.

2.109 Curatio calide et humide distperantie [sic] (Lyons 1504, 53v-[5]4r)

... Carnes autem recentes edulina cunarum $^{11112}$ spondilis ${ }^{113}$ asp(er)agus ${ }^{114}$ brionia et salsamenta omnia....

\section{Clindonas}

A

Clindonas greci Alexander ca. de ventositate splenis, clidonas enim greci vocant quando agitatur aqua sicut in utre ita in ventre.

B

Clidonas [sic] g(_). Alexan. ca. de uentositate splenis clidonas [sic] enim gre. uocant quando agitatur aqua sicut in utre ita in uentre.

2.115 De ventositate splenis (Lyons 1504, [5]4r)

... Chimodas $[\mathrm{sic}][\mathrm{ms} \text {. A = Clidonas }]^{115}$ namque Greci dicunt quando agitatur sicut in utre aqua ita et in ventre...

108 2.104-50: Lyons 1504, 53r-59r.

109 + gloss '"g"': 'Artomelli grece panis cum melle factus. Ian(_).' (56r).

110 Cf. Masullo Rita, Filagrio: Framenti (Naples: Bibliopolis, 1999), 332.437: artomeli [+ variants]; cf. Mihăileanu, Fragmentele latine..., 170.24: artomele [+ variants, 170-1]; cf. Puschmann, Nachträge zu Alexander Trallianus..., 102: artomelle [+ n. 128: ảpró $\mu \varepsilon \lambda \mathrm{l}]$.

111 + gloss 'o': 'id est anser.' (53v).

112 Cf. Masullo, Filagrio..., 316.93: cinnara [+ variants]; cf. Mihăileanu, Fragmentele latine...,152.10: cinnara [+ variants]; cf. Puschmann, Nachträge zu Alexander Trallianus..., 78 : cinara [+ variants].

113 + gloss 'p': 'id est caro spondilium.' (53v).

114 + gloss 'q': 'id est sp(er)agus.' (53v).

115 Cf. Masullo, Filagrio..., 319.161: Clidonas [no variants]; cf. Mihăileanu Fragmentele latine..., 155.16: Clidonas [no variants]; cf. Puschmann, Nachträge zu Alexander Trallianus..., 84: Clydonas [no variants]. 


\section{Epilata}

A

Epilata .g. medicine laxative per os sumpte ut Alex.ca. de splene, nunc ergo dicendum et cetera, sunt maxime leves ut idem infra de epilatibus illa ergo danda et cetera.

B

Epilata gr(_). medi(_)e laxati(_)e per os sumpte ut Alex. capitulo de splene nunc ergo dandum [sic] est et cetera. sunt maxime lenes [sic] ut idem infra de opilato(n)ibus [sic] illa igitur danda et cetera.

2.121 Curatio flegmonis in splene generati (Lyons 1504, 55r)

[N] unc igitur dicendum est de inflammatione in splene generata. ... Alie quidem euacuationes sunt que per ventrem deponunt ${ }^{116}$ quas Greci epilatas ${ }^{117}$ vocant que sunt in primis utende....

\subsection{De epilatibus ${ }^{11819}$ (Lyons $1504,55 r$ )}

[E]pilata ${ }^{120}$ igitur danda sunt que euacuare solent per ventrem qui continentur humores post flobothomum: habebis enim in hiis exemplum sicut in quarto libro de podagricis scriptum est. Sunt enim epilata leuia medicamenta qualia sunt herba mercurialis et polipodium et gincus ${ }^{121}$ et acalafis $^{122}$ semen et hiis similia.

2.127 De catartico aut apozimate vel inunctionibus (Lyons 1504, 56r)

[C]um ergo meliorata fuerit passio mutanda sunt adiutoria et purgandus est venter de epilatis ${ }^{123} 124$ mitibus per os datis coctis in ptisanis / aut cum aqua danda sunt ad bibendum....

2.134 Curatio scyron splenis (Lyons 1504, 57r)

... Tunc a nobis duobus aut tribus diebus epilatis ${ }^{125} 126$ catarticis purgatus est. ...

2.137 De sanguine tollendo (Lyons 1504, 57r-57v)

... Postea autem cum bene resolutum esset splen de epilatis $^{127}$ dedi catarticis et euacuaui vacantes humores per ventrem fortioribus medicamentis [57v] id est antidotis dyacolloquintidos yere ...

116 + gloss 'e': 'id est euacuant.' (55r).

117 Cf. Masullo, Filagrio..., 325.272: epilata [+ variant]; cf. Mihăileanu, Fragmentele latine..., 161.7): epilata [no variants]; cf. Puschmann, Nachträge zu Alexander Trallianus..., 92: hypelata [+ n. 73: úmńर $\alpha \tau \alpha]$.

118 + gloss 'h': 'id est medicine laxatiue per os sumpte [sic]. lan(_).' (55r).

119 Cf. Masullo, Filagrio..., 325.293: epilatis [+ variants]; cf. Mihăileanu, Fragmentele latine..., 162.13): epilatis [+ variants]; cf. Puschmann, Nachträge zu Alexander Trallianus..., 92: hypelatis [no variants].

120 Cf. Masullo, Filagrio..., 325.293: Epilata [no variants]; cf. Mihăileanu, Fragmentele latine..., 162.13: Epilata [no variants]; cf. Puschmann, Nachträge zu Alexander Trallianus..., 92: Hypelata [no variants].

121 + gloss 'i': 'gincus est crocus hortulanus. lan(_).' (55r).

$\mathbf{1 2 2}+$ gloss 'k': 'id est urtice.' (55r).

123 + gloss 'b': 'id est medicinis laxatiuis per os assumpis. [sic]' (56r).

124 Cf. Masullo, Filagrio..., 330.386: epilatis [+ variants]; cf. Mihăileanu, Fragmentele latine..., 168.5): epilatis [no variants]; cf. Puschmann, Nachträge zu Alexander Trallianus..., 98: hypelatis [no variants].

$\mathbf{1 2 5}+$ gloss 'd': 'id est medicinis laxatiuis per os sumptis. [sic]' (57r).

126 Cf. Masullo, Filagrio..., 336.522: epilatis [no variants]; cf. Mihăileanu, Fragmentele latine..., 175.11: epilatis [no variants]; cf. Puschmann, Nachträge zu Alexander Trallianus..., 108: hypelatis [no variants].

127 Cf. Masullo, Filagrio..., 338.567: epilatis [no variants]; cf. Mihăileanu, Fragmentele latine..., 177.11: epilatis [no variants]; cf. Puschmann, Nachträge zu Alexander Trallianus..., 110-112: hypelatis [no variants]. 


\section{Epythyma ypotirion}

A Epythyma ypotirion idem Alex. de splene.

B Epithima ypotirion idem Alex. capitulo de splene.

2.145 Epithima ypotirion ${ }^{128}$ (Lyons 1504, 58v)

[S] unt autem et alia epithimata ${ }^{129}$ ad spleneticos et ydropicos que nominantur ypotirion ${ }^{130} \ldots$

\section{Eukrion}

A Eukrion Alex. de cura ventositatis splenis prassii eucrion et cetera.

B Eukrion Alex. de cura uentositatis splenis prassii eukrion et cetera.

2.116 Curatio ventositatis (Lyons 1504, [5]4r-[5]4v)

$[[5] 4 \mathrm{v}]$... Sed et alia sunt qualis est herpillus et thimus et lauri cortex et origanum. Et calamentum siccum et viride et piper et ruthe semen / et maxime si siluestris sit et pencedanum ${ }^{131}$ [sic] et maxime opos $^{132}$ ipsius et costum et cardamomum et prassium. et eucrion ${ }^{133} 134$ [ms. A = ucrion] et centaurea subtilis...

\section{Omotribum oleum}

Omotribum oleum Alex. ca. de cephalea, omotribus oleum inquit octobriscum et cetera. Idem in ca. de fomentis ad splenis inflationem. Item in ca. de linimentis ad podagram calidam, oleo inquit omotribio quod primo tempore fit et recipit folia olive ut sit amarum et cetera, Ga. vero .xi. de ingenio, oleum onfacinum, ab aliis vero omotriuos i. ex acerbis olivis constructum et cetera.

Omotribum oleum Alex. ca. de cephalea omotribum ol(eu)m inquit .i. octobriscum et cetera idem in ca. de linimentis idem in c. de fomentatione ad splenis in fla(_)ationem B idem in capitulo de linimentis ad podagram calidam oll(e)o [sic] inquit omotribio quod primo tempore fit et recipit folia oliue ut sit amarum et cetera. Gal(_) vero in io [sic] de ingenio sanitatis ol(eu)m onfaci(n)um [sic] ab aliis uero omotrinos [sic] .i. ex acerbis oliuis constructum et cetera.

128 Cf. Masullo, Filagrio..., 348.765: Epitima ypotirion [+ variants]; cf. Mihăileanu, Fragmentele latine...,186.1: Epitima ypotirion [+ variants]; cf. Puschmann, Nachträge zu Alexander Trallianus..., 120: Epithema hypotherion [no variants].

129 Cf. Masullo, Filagrio..., 348.766: epitimata [no variants]; cf. Mihăileanu, Fragmentele latine...,186.1: epitimata [no variants]; cf. Puschmann, Nachträge zu Alexander Trallianus..., 120: epithemata [no variants].

130 Cf. Masullo, Filagrio..., 348.766: ypotirion [+ variants]; cf. Mihăileanu, Fragmentele latine...,186.2: ipoterion [+ variants]; cf. Puschmann, Nachträge zu Alexander Trallianus..., 120: hypotheria [no variants].

131 + gloss 'm': 'id est feniculus porcinus.' ([5]4v).

132 + gloss ' $n$ ': 'id est succus.' ([5]4v).

133 + gloss 'o': 'eukrion per k scribit ianuensis allegans hunc passum. sed non exponit extimo quod sit eupatorium.' ([5]4v).

134 Cf. Masullo, Filagrio..., 321.197: teucrion [+ variants]; cf. Mihăileanu, Fragmentele latine...,157.11: teucrion [+ variants]; cf. Puschmann, Nachträge zu Alexander Trallianus..., 86: teucrium [no variants]. 
2.123 De fomentationibus (Lyons 1504, 55r-55v)

[55v] ... Quod si calor sit mittendum est oleum omotribe ${ }^{135} 136$ et rosa....

[Not 'Philagrius section'] 2.155 De ydrope asclite et tympanite (Lyons 1504, 68v) ... Nihilominus autem faciende sunt fricationes cum sale et oleo omotribro ${ }^{137}$ [sic] [for Greek

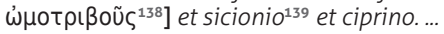

[Not 'Philagrius section', section on gout] 2.245 De amplastris (76r-76v)

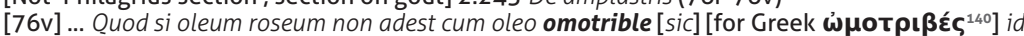
est amaro quod primo tempore fit et recipit folia oliue ut sit amarum utilissimum est....

[Not 'Philagrius section'] 1.40 Curatio cephalargicorum (Lyons 1504, 6r-6v) ... oportet adhibere et fomentationes cum altea vel oleo aut herbis in aqua coctis non satis calidis sed et robur habentibus ut confortare valeant caput quale est omotribem [6v] id est octobrinum

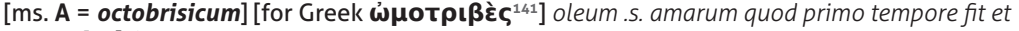
accipit [sic] folia oliue ut sit amarum. utilissimum enim est ...

\section{Pegmata}

A

Pegmata.g. Alex. ca. de dieta inflationis splenis li. de doctrina .g. pegmata vel pigmata vel pigmenta.

B

Peginata [sic] gr(_). Alex. ca. de dieta inflationis splenis liber de doctrina gr(_) peginata [sic] pigmata pigmenta: [sic]

2.105 Signa frigide distemperantie splenis (Lyons 1504, 53r)

... Qualia sunt aqua frigida ostrea sterilis ${ }^{142}$ caro porcina pomorum copia accepta et diuersa poma

$[\mathrm{ms} . \mathbf{A}=\text { pimmata }]^{143}$ et maxime in estate accepta....

135 + gloss 'b': 'id est oleum oliuarum quod primo tempore fit et recipit folia oliue ut sit amarum. lanuensis.' (55v).

136 Cf. Masullo, Filagrio..., 326.313: omotribe [+ variants]; cf. Mihăileanu, Fragmentele latine...,164.1: omotribe [+ variants]; cf. Puschmann, Nachträge zu Alexander Trallianus..., 94:

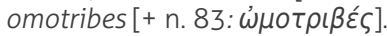

137 + gloss 'e': 'id est oleum oliuarum quod primo tempore fit et recipit folia oliue ut magis sit amarum.' (68v).

138 Puschmann, Alexander von Tralles..., II.449.33.

139 + gloss ' $f$ ': 'id est de radice cucumeris agrestis.' (68v).

140 Puschmann, Alexander von Tralles..., II.517.20.

141 Puschmann, Alexander von Tralles..., I.491.1

142 + gloss 'r': 'id est omasa.' (53r).

143 Cf. Masullo, Filagrio..., 312.15: pemmata [+ variants]; cf. Mihăileanu, Fragmentele latine...,148.16: pemmata [+ variants]; cf. Puschmann, Nachträge zu Alexander Trallianus..., 74: pemmata [+ variants]. 


\section{Sisti}

A Sisti etiam aliquando pro eodem alumine reperitur et etiam pro arsenico nam utrumque scissile est ut Alex. confectione ethionica ad splenem.

B Sisti etiam aliquando pro eodem alu $(m)$ i(n)e reperitur et etiam pro arsenico nam utrumque scisille [sic] est ut Alex. in confle)c(ti)one epithonica [sic] ad splenem.

2.141 Confectio epithimatis atonotici144 ad splen [sic] confortandum (Lyons 1504, 58r)

[M] dicamen quod supra diximus de arsenico et stipterea et confortatio ad splenem seu splenis athomam ${ }^{145}$ quam superposui homini illi quem sepius memorauimus. quod recipit ... arsenici

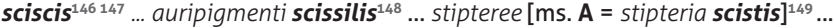

$\mathbf{1 4 4}+$ gloss 'b': 'id est confortatiui seu roboratiui.' (58r).

$\mathbf{1 4 5}+$ gloss 'c': 'debilitatem. lan(_).' (58r).

$\mathbf{1 4 6}+$ gloss 'e': 'a loco.' (58r).

147 Cf. Cf. Masullo, Filagrio..., 344.692: scisto [+ variants]; cf. Mihăileanu, Fragmentele latine..., 181.18: scisto [+ variants]; cf. Puschmann, Nachträge zu Alexander Trallianus..., 116: scissi [no variants].

148 Cf. Masullo, Filagrio..., 344.693: scissili [+ variants]; cf. Mihăileanu, Fragmentele latine..., 181.19): scissili [+ variants]; cf. Puschmann, Nachträge zu Alexander Trallianus..., 116: omitted, and no variants.

149 Cf. Masullo, Filagrio..., 344.693: scistis [+ variants]; cf. Mihăileanu, Fragmentele latine..., 181.19-182.1: stipteria scistis [+ variants]; cf. Puschmann, Nachträge zu Alexander Trallianus..., 116: stypteriae scissilis [no variants]. 